\title{
PUBLIC LAW ASPECTS IN THE EMPLOYMENT OF UNIVERSITY TEACHERS IN THE LIGHT OF THE ACT: LAW ON HIGHER EDUCATION AND SCIENCE
}

\begin{abstract}
In spite of its obligation-based nature, the contractual employment relationship of university teachers still has some properties that make it similar to the structure of a public law service relationship. Here, the specificity of the employment of university teachers is determined by the elements of content of their employment relationship that are closely linked to the realisation of the government's duties related to science and higher education. The different employment status of university teachers is in fact a heterogeneous solution, where the obligation-based nature of the employment relationship is complemented with elements that are characteristic for public law service relationships.
\end{abstract}

Słowa kluczowe: nauczyciel akademicki, uczelnia, publiczny charakter zatrudnienia, funkcje publiczne Keywords: academic teacher, university, public law aspects in the employment, public functions ASJC: 3308 , JEL: K31

\section{General remarks}

The different status of academic teachers in terms of their employment is a consequence of the degree of autonomy and independence of universities as specific organisational structures (Sanetra 2015, p. 19). In the preamble to the Act of 20 July 2018-Law on higher education and science (Dz.U. 2020, item 85 consolidated text, as amended, hereinafter referred to as: LHES), the legislator points out that higher education institutions and other research institutions realise a mission of special importance for the state and the nation. They make a vital contribution to the innovative economy, foster cultural development and co-create moral standards that are binding in the public life. Statutes of higher education institutions elaborate on the content of the quoted declaration by providing more prescriptive definitions of the mission of the given university and the immanently linked tasks of university teachers. 
The employment section of the LHES plays the role of a pragmatic regulation as defined in Art. 5 of the Labour Code (Dz.U. 2019, item 1040 consolidated text, as amended, hereinafter referred to as: "the Labour Code," "l.c."), by defining the norms addressed to academic staff members, first of all teachers. Moreover, as any employment pragmatics (Seler 1974, pp. 4 ff; Liszcz 1989, pp. 24 ff; Ćwiertniak 1992, pp. 8 ff; Ćwiertniak 2009, pp. $33 \mathrm{ff}$; another category of pragmatics are service pragmatics that define the legal status of persons who perform work under administration law relationship), being an instrument of subjective differentiation of labour law (Wagner 2006, p. 156), it adjusts the normative regulations to the specificity of employment in the given sector or profession (Baran 2010, p. 375), which, in this case, is the organisational sphere of the higher education and science system. This regulation meets the requirement of differentiating employment relationships in order to take into account their differences and to comply with the principle of rationality of the legal system. The internal diversification of the Act, which is based mainly on kinds of universities, types of employment or the positions of academic teachers, implies a multi-faceted nature of the differentiation of employment of university teachers, while, at the same time, distinguishing the criteria for differentiation, both in objective and subjective terms, as well as in the functional aspect (Lekston 2010, pp. $159 \mathrm{ff}$ ). These mechanisms refer both to the stage of entering in an employment relationship and to shaping its content, modifying it, and terminating the employment of a university teacher.

Although differentiating employee rights based on the public or private nature of the employing entity is essential in common labour law (Sobczyk 2013, p. $104 \mathrm{ff}$; the Author lists the form of ownership as one of the criteria for the division of employing entities, apart from the aim-subject-of employment, organisational form, and the number of employees), and in the employment relationship it is the content of one of the aspects of subjective differentiation, considering the subject of this study it seems reasonable to make the reservation that this kind of differentiating factor is indifferent for our considerations. These results from the fact that the presence of public law elements in the obligatory employment relationship of university teachers is caused by the specificity of employment in this role, regardless of whether the university is a public or non-public institution. At the same time, this aspect may present certain uniform elements, which, in fact, makes it even more reasonable to analyse the employment relationship of university teachers in genere in terms of the presence of public law aspects.

\section{General characteristics of the employment of university teachers}

Based on the assumption that certain elements of the employment relationship of university teachers are of a public law nature, one should first of all determine its legal nature, mainly viewed through the prism of delimitation between a public law professional relationship and obligation-based employment relationship. Both historical reasons and the content of binding standards of the LHES allow us to state that the main factor 
of differentiation defined in this way seems to be the basis of employment of university teachers and the legal qualification of the act of appointment used for this purpose, whose evolution in recent decades has also influenced the status of employment in the higher education sector.

In the temporal approach proposed in the doctrine (Jastrzębski 2015, pp. $44 \mathrm{ff}$ ), regulations concerning the functioning of higher education institutions in Poland and thus the related model of university teachers' employment may be divided into three main stages, i.e. the period of the 2nd Republic, then the years 1945-1989, and finally the period after 1990. In the first of these periods, the basis for the employment of university teachers, apart from few exceptions for contract workers, was the appointment that created a service relationship of an administrative legal nature (the Act of 13 July 1920 on academic institutions, Dz.U. 1920, No. 72, item 494 as amended; the Ordinance of the President of the Republic of Poland of 24 February 1928 on the service relationship of professors of public academic institutions and auxiliary academic staff of such schools, Dz.U. 1933, No. 76, item 551; the Act of 15 March 1933 on academic institutions, Dz.U. 1938, item 6 consolidated text, as amended). Later, during the post-war period until the year 1990, an evolution in the nature of the act of appointing university teachers could be observed. This meant, in fact, a gradual deviation from the principle stating that appointment-based employment relationships always mean creating a public law relationship, and thus the employed person is actually not an employee. The employment of university teachers has become obligation-based, not only if the teacher was employed pursuant to an employment contract, but also pursuant to an act of appointment. ${ }^{1}$ Normative prerequisites for treating university teachers as individuals subject to obligation-based employment relationships, not to the regimen of an administration law service relationship were provided in the Act of 5 May 1982 on higher education (Dz.U. 1985, No. 42, item 201 consolidated text, as amended). At the same time, due to political conditions, as an element of a kind of "bribe" for the academic circles (Jastrzębski 2015, p. 33), appointed university teachers were guaranteed a far-reaching stability of employment, which is characteristic for service relationships based on appointment. After the political transformation, appointment initially remained the main basis for entering in an employment relationship with university teachers. ${ }^{2}$ However, obligation-based employment relationships were developed consist-

${ }^{1}$ During the period when, subsequently, the Decree of the Council of Ministers approved by the Council of the State of 28 October 1947 on the organisation of science and higher education, the Act of 15 December 1951 on higher education and academic staff (Dz.U. 1956, No. 45, item 205 consolidated text, as amended), the Act of 5 November 1958 on higher education (Dz.U. 1973, No. 32, item 191 consolidated text), the Act of 27 April 1972-Charter of teacher's rights and obligations (Dz.U. 1972, No. 16, item 114 as amended), a normative confirmation of this trend was the entry into force of the Labour Code in 1975. It sanctioned expressis verbis the principle that employment relationship may also be established by appointment.

${ }^{2}$ As in the Act of 12 September 1990 on higher education (Dz.U. 1990, No. 65, item 385 as amended), where the employment contract was used if the higher education institution was treated as an additional 
ently, to finally create a clearly dualist system of the basis for establishing employment relationships with academic teachers, based both on an employment contract and the act of appointment (the Act of 27 July 2005-Higher education law, Dz.U. 2017, item 2183 consolidated text, as amended). Finally, it was assumed that appointment-based employment would be limited only to University teachers who hold the degree of Professor (the Act of 18 March 2011 amending the acts-Higher education law, the Act on academic degrees and title and arts degrees and title and amending certain other acts, Dz.U. 2011, No. 84, item 455).

De lege lata, pursuant to Art. 117 of the LHES, academic staff members are employed pursuant to an employment contract, which means that the legislatory authority decided not to apply appointment as a basis for employing university teachers. At the same time, in the framework of the intertemporal mechanism, pursuant to Art. 248 of the Act of 3 July 2018 implementing the Act on higher education and science, Dz.U. 2018, item 1669), academic staff members employed by universities on the basis of appointment on the date of entry into force of the LHES will remain employed in the same form and for the same period.

Considering the above, it may be assumed that the evolution of the employment of university teachers in Polish higher education system is characterised by two co-existing tendencies. Abandoning the appointment-based employment relationships of a service nature was accompanied by a gradual transformation of the act of appointment into an action of labour law that creates an obligation-based employment relationship.

\section{Public law features of the employment relationship of university teachers}

In spite of its obligation-based nature, the contractual employment relationship of university teachers still has some properties that make it similar to the structure of a public law service relationship. This conclusion is justified, for example, in the light of the fact that an organ located outside the higher education domain is authorised to shape the professional status of university teachers (e.g. actions taken by the competent minister towards a university teacher who holds the position of rector, including actions concerning disciplinary liability or in the proceedings for granting the academic title of Professor; Kuczyński 2020, p. 65).

Here, the specificity of the employment of university teachers is determined by the elements of content of their employment relationship that are closely linked to the realisation of the government's duties related to science and higher education. Considering the specific statutory solutions that shape the elements of the employment relationship of university teachers, one may conclude that such normative characteristics define the 
limits of freedom of parties to an individual employment relationship to determine its content. Wherever legislation defines the rights and obligations of university teachers in a manner similar to public law employment, the possibility to shape their particulars is limited or even excluded (e.g. principles of disciplinary liability). The freedom of parties to shape the content of a university teacher's employment relationship, subject to compliance with the principle of respect for the employee, will only be possible in those cases where the pragmatics foresees mechanisms that are characteristic for obligation-based nature of the employment relationship or creates references to the provisions of the Labour Code.

The exemplification method may be used to quote those normative elements of the employment relationship content that are of key importance in determining the specificity of employment of university teachers within the framework of the adopted assumptions.

The LHES provides regulations that determine a specific approach to employee competence, different from that defined by the provisions of the Labour Code. These regulations should be treated as norms that define so-called selection regimens, i.e. statutory requirements that must be met by a person applying to be employed as a university teacher, although the requirements listed expressis verbis in the Act should be considered as minimum (Sanetra 2013, pp. 238-239). What is important, meeting specific requirements applies not only to the stage of entering in an employment relationship, but also the possibility to continue employment as a university teacher. This is why it seems reasonable to use the term "competences" instead of "qualifications," because failure to meet the requirements disqualifies the given person from holding a specific position or performing a specific type of work (Sobczyk 2018, p. 485). Both in historical terms and de lege lata, the requirements being part of selection regimens focus on possessing a specific academic or professional title or degree, depending on the position. Secondly, they refer to having full legal capacity, full public rights, a clear penal record with respect to specific types of offences, or the absence of disciplinary penalties that would exclude the possibility to work as a university teacher. Considering the aim of the regulation that defines increased standards of employee competences, one may formulate the thesis that this type of mechanism is characteristic for the possibility of being employed on an employment (e.g. Art. 6 of the Act of 21 November 2008 on selfgovernment employees, Dz.U. 2019, item 1282 consolidated text; Art. 4 of the Act of 21 November 2008 on civil service, Dz.U. 2020, item 265 consolidated text) or service basis (e.g. Art. 25 of the Act of 6 April 1990 on the Police, Dz.U. 2020, item 360 consolidated text, as amended) in widely understood public administration or uniformed services. The public law context is clearly noticeable here, if we consider the duties of employing entities in such services, which determine the scope of actions of employees and officials secondarily.

Another specific structure in the employment of university teachers that may match the scope of public law aspects in their employment relationship is the regulation of the primary and secondary place of work (see more: Cudowski 2007; 2015; PakułaGawarecka 2013, pp. 27 ff; Pudełko 2011, pp. 572 ff; 2012, pp. 293 ff; Lekston 2007). 
Although the normative mechanism of limiting professional activity is also known in other employment pragmatics (e.g. Art. 80 of the Act of 21 November 2008 on civil service), the provisions of the Law on higher education define it in a specific way. First of all, it should be assumed that defining the main place of work of university teachers and the control of employment in secondary places of work, as well as limiting their possibility to conduct business activity are closely connected to the changes resulting from the political transformation and the expansion of non-public higher education institutions after 1990. In this context, it is symptomatic, for example, that for a long time, employment at the main or additional place of work was considered by universities as a condition to possess the competences to teach a specific level or faculty, as one of the elements of the so-called minimum academic staff complement. Considering the ratio legis of limiting the professional activity of university teachers de lege lata, the legislatory authority does not specify circumstances that might justify the refusal to grant consent for employment at the additional place of work, which makes this decision seem arbitrary and discretionary. ${ }^{3}$ However, one may claim that the aim of the mechanism of main place of work and the necessity to obtain permission for employment at the additional place of work was to ensure high quality of teaching and scientific work of academic staff by focusing their activities generally in one place of work. Moreover, the analysed structure may be viewed through the prism of aspects of competitiveness on the higher education market. Referring the discussed problem to the status of university teachers it should be added that the existence of limitations of their additional activity confirms the thesis about the presence of public law elements in their employment relationship. It should be considered that the obligation to obtain a decision of the rector of the higher education institution being the main place of work for the university teacher to obtain consent or refusal to consent for work at the additional place does not shape the rights or obligations in an obligation-based dimension, but is clearly external to the employment relationship between the parties. Moreover, it contributes to limiting the freedom of work (Baran 2020, pp. 131-132), which, in employment law, is generally characteristic for administration law service relationships.

Another reference to traditional service law solutions, which also positions the status of university teachers on the public law level (Kuczyński 2020, pp. 81-82) are the provisions of the LHES that forbid direct supervisor or subordinate relationship in the higher education institution between close relatives or persons maintaining the same household. Even without a detailed analysis of the subjective scope of the norm provided in Art. 118 of the LHES and the lack of a precise definition of a direct supervisor or subordinate relationship (Książek 2020, p. 75), it should be emphasised

${ }^{3}$ In the previous legal state, pursuant to Art. 129, item 2 of the LHE, the rector refused consent for additional employment is performing teaching or academic services for a different employer reduced the university's capacity for proper functioning or was connected with using its technical equipment or resources. 
that this type of structure is characteristic for the public administration domain (Art. 26 of the Act of 21 November 2008 on self-government employees), and its aim is to eliminate the suspicion of influence of family relations on the performance of duties resulting from the position held in widely understood public administration structures. It should ensure both objectivity and professionalism. Transferring such solution to the domain of higher education, regardless of the public or non-public nature of the given institution, may raise some doubts concerning the interference of the legislator with the sphere of autonomy of universities. On the other hand, considering the topic of this study, the provision forbidding direct supervisor or subordinate relationship between close relatives is a clear manifestation of the public law nature of the employment of university teachers.

The analysis of public law aspects in the obligation-based employment relationship of university teachers should also refer to the structure of disciplinary liability in this context. Setting aside the relevant regulations of the LHES, the scope of actions defined in Art. 275 of the Act as work performance or conduct that is considered to breach accepted professional and ethical standards and result in university teachers being liable to disciplinary liability are symptomatic. Especially in the second aspect that refers to the professional standards of university teachers, their disciplinary liability may be perceived through the prism of a specific personification of the duties of the institution and of the whole higher education system. Breach of professional standards, which is also used in other pragmatic regulations (Art. 107 of the Act of 21 July 2007-Law of the common courts system, Dz.U. 2020, item 365 consolidated text, as amended) as a basis for defining disciplinary offences, refers to any conduct or actions that may discredit the profession, which is perceived in its social dimension as a public trust profession. As far as academic staff is concerned, these may be in particular actions related to abusing the relation of subordination in order to force certain behaviour, accepting bribes, low personal culture or scientific misconduct (Ura 2020, p. 461). It is doubtless that such actions may also be correlated with non-performance or improper performance of employee's duties, but one should agree with the statement that they should be categorised in a wider scheme, in reference to the social position of a university teacher as an employee of the university, which, in its public dimension, is an element of the higher education and science system (the provisions of Section VII of the ActLaw on higher education and science and the provisions of the Ordinance of the Ministry of Higher Education and Science of the 25 September 2018 on the specific mode of mediation, clarification and disciplinary proceedings in cases of disciplinary liability of university teachers, as well as the manner of enforcement and expungement of disciplinary penalties, Dz.U. 2018, item 1843).

Another pragmatically conditioned element of university teachers' employment relationship is the system of assessing their work and the influence of the assessment on the duration of the employment. The mechanism of employee assessment originates from service employment relationship based on appointment, where it was an instrument for verifying the suitability of the given person for work considering limited termination 
possibilities as a result of increased employment protection (Żywolewska 2015, p. 347). Although periodical assessment of university teachers may be considered as a means that motivates them to update and improve their professional qualifications and good work quality (Jackowiak 2009, p. 470), it is worth noting that the assessment also affects the possibility to promote the teacher in the organisational structure of the University or implies actions aimed as the dismissal of such person or transfer to a different position (Szewczyk 2011, p. 452). Moreover, Art. 124 item 2 of the LHES states that two successive negative assessments result in the termination of the employment relationship. What is important, in this context filing a statement on termination of the employment relationship is obligatory, which is, again, characteristic for service employment.

In the convention adopted for this study it is also worth noting that the performance of professional duties by university teachers implies certain consequences that may be viewed in public law terms. Pursuant to art. 115, item 1 (2) of the LHES, the duty of a university teacher employed in a research staff group is to conduct scientific activity, which is manifested, in particular, in their publications. The type and scale of this activity is one of the prerequisites for the higher education institution to be assigned a specific scientific category as part of evaluation of its scientific activity (art. 265 and subsequent articles of the LHES), which, in turn, pursuant to Art. 185, item 1 and Art. 218 of LHES, results in acquiring, by virtue of law, the right to grant the academic degrees of doktor and doktor habilitowany. The nature of such authorisation clearly qualifies as public law as a result of the structure of academic degrees and titles in the Republic of Poland.

\section{Performing public functions by university teachers}

The discussed aspects of the public law employment of university teachers allow us to classify their positions as persons who perform public functions, although the scope of the notion is quite different and it is not identical to that provided in the definition of a public official. Public functions are performed by persons who perform functions that are connected with a certain extent of rights and obligations resulting from the realisation of tasks of public importance (judgment of the Voivodeship Administrative Court in Gliwice of 31 May 2016, IV SAB/Gl 52/16, Legalis). According to well-established views of the judiciary (decision of the Supreme Court of the 25 June 2004, V KK 74/04, Legalis; judgment of the Supreme Administrative Court of 18 August 2010, I OSK 775/10, LEX 737508; judgment of the Supreme Administrative Court of 19 April 2011, I OSK 125/11, CBOSA; judgment of the Supreme Administrative Court of 30 January 2014, I OSK 1978/13, CBOSA; judgment of the Supreme Administrative Court of 10 April 2015, I OSK 1108/14, CBOSA; judgment of the Supreme Administrative Court of 8 July 2015, I OSK 1530/14, CBOSA), the conduct of a university teacher connected with performing their duties are the realisation of one of the constitutional tasks of the State (Art. 70, item 1 of the Constitution of the Republic of Poland), which meets the criterion for performing public function. In this light, one may additionally emphasise 
that the positioning of university teachers as persons who perform public functions results mainly from their membership in commissions that decide on granting professional titles or academic degrees. The public or non-public nature of the institution that employs the university teacher is irrelevant for this conclusion. At the same time, it should be pointed out that university teachers are not public officials, as they have not been listed as a subject in Art. $115 \$ 13$ of the Penal Code (Dz.U. 2019, item 1950 consolidated text, as amended). Moreover, due to the absence of the relevant standard in the LHES Act, university teachers are not subject to protection foreseen for public officials when performing their duties. This may be treated as an obvious disadvantage and a lack of consequence of the legislator, who has foreseen such structure for school teachers who are subject to the regulations of the Teacher's Charter (Dz.U. 1972, No. 16, item 114 as amended). ${ }^{4}$ Considering the identical prerequisites for performing a public function, the differentiation between school and university teachers can hardly be considered justified. De lege ferenda it would be reasonable to call for adding relevant provisions, modelled on those in the Teacher's Charter, to the LHES.

\section{Conclusion}

Although the normative solution consisting in the uniformization of the act that defines the employment relationships of university teachers means that the legislator deviates from the employment relationship model similar to administration law service relationships, at the same time it maintains the separate status of university teachers in reference to workers employed under the provisions of the Labour Code. The employment structures that constitute this separateness are noticeably characterised by public law elements.

Thus, it seems justified to conclude that the different employment status of university teachers is in fact a heterogeneous solution, where the obligation-based nature of the employment relationship is complemented with elements that are characteristic for public law service relationships.

\section{References}

Baran K. W. (2010) Źródła prawa pracy [in:] K. W. Baran (red.), Zarys systemu prawa pracy, t. 1: Część ogólna prawa pracy, Warszawa.

Baran K. W. (2020) [in:] K. W. Baran (red.), Akademickie prawo zatrudnienia, Warszawa. Cudowski B. (2007) Dodatkowe zatrudnienie, Warszawa.

\footnotetext{
${ }^{4}$ Pursuant to art. 63, item 1 of the Teacher's Charter, the teacher, during or in connection with performing professional duties, is subject to protection foreseen for public officials on the terms specified in the Penal Code.
} 
Cudowski B. (2015) Dodatkowe zatrudnienie nauczycieli akademickich zatrudnionych w uczelniach publicznych [in:] W. Sanetra (red.), Zatrudnienie nauczycieli akademickich, Warszawa.

Ćwiertniak B. M. (2009) O procesach przemian pragmatyk zawodowych w ostatnim dwudziestoleciu (kilka refleksji) [in:] Z. Góral (red.), Z zagadnień współczesnego prawa pracy. Księga jubileuszowa Profesora Henryka Lewandowskiego, Warszawa.

Ćwiertniak B. M. (1992) Pragmatyki zawodowe (stan obecny i perspektywy przemian), "Z Problematyki Prawa Pracy i Polityki Socjalnej," t. 7.

Jackowiak U. (2009) Mechanizmy prawne stymulujące pożądany poziom kwalifikacji nauczycieli akademickich [in:] Z. Góral (red.), Zzagadnień współczesnego prawa pracy. Księga jubileuszowa Profesora Henryka Lewandowskiego, Warszawa.

Jastrzębski R. (2015) Polskie regulacje ustawowe w zakresie zatrudnienia nauczycieli akademickich w XX wieku [in:] W. Sanetra (red.), Zatrudnienie nauczycieli akademickich, Warszawa.

Książek D. (2020) [in:] K. W. Baran (red.), Akademickie prawo zatrudnienia, Warszawa.

Kuczyński T. (2020) [in:] K. W. Baran (red.), Akademickie prawo zatrudnienia, Warszawa.

Lekston M. (2007) Podstawowe i dodatkowe miejsce pracy nauczyciela akademickiego w świetle ustawy Prawo o szkolnictwie wyższym, "Studia z Zakresu Prawa Pracy i Polityki Społecznej."

Lekston M. (2010) Dyferencjacja zatrudnienia w szkole wyższej. Analiza kryteriów, "Studia z Zakresu Prawa Pracy i Polityki Społecznej."

Liszcz T. (1989) Rekodyfikacja prawa pracy a pragmatyki pracownicze, "Praca i Zabezpieczenie Społeczne," nr 6.

Pakuła-Gawarecka P. (2013) Charakter prawny zgody rektora na podjęcie dodatkowego zatrudnienia przez nauczyciela akademickiego [in:] B. M. Ćwiertniak (red.), Aktualne zagadnienia prawa pracy i polityki socjalnej, Sosnowiec.

Pudełko W. (2011) Zgoda na dodatkowe zatrudnienie nauczyciela akademickiego, "Monitor Prawa Pracy," nr 11.

Pudełko W. (2012) Charakter prawny norm ograniczajacych dodatkowe zatrudnienie nauczycieli akademickich, "Studia z Zakresu Prawa Pracy i Polityki Społecznej."

Sanetra W. (2013) [in:] W. Sanetra, M. Wierzbowski (red.), Prawo o szkolnictwie wyższym. Komentarz, Warszawa.

Sanetra W. (2015) Ogólnie o odrębności statusu zatrudnienia nauczycieli akademickich [in:] W. Sanetra (red.), Zatrudnienie nauczycieli akademickich, Warszawa.

Seler R. (1974) Pragmatyki pracownicze a kodeks pracy, "Praca i Zabezpieczenie Społeczne," nr 12. Sobczyk A. (2018) [in:] A. Sobczyk (red.), Kodeks pracy. Komentarz, Warszawa.

Sobczyk A. (2013) Prawo pracy w świetle Konstytucji RP, t. 2: Wybrane instytucje prawa pracy a konstytucyjne prawa $i$ wolności człowieka, Warszawa.

Szewczyk H. (2011) Regulacja statusu prawnego nauczycieli akademickich zatrudnionych w uczelniach publicznych a rozwój nauki (wybrane zagadnienia) [in:] L. Florek, Ł. Pisarczyk (red.), Współczesne problemy prawa pracy i ubezpieczeń społecznych, Warszawa.

Ura E. (2020) [in:] K. W. Baran (red.), Akademickie prawo zatrudnienia, Warszawa.

Wagner B. (2006) Stosunek pracy i jego treść [in:] M. Matey-Tyrowicz, T. Zieliński (red.), Prawo pracy RP w obliczu przemian, Warszawa. 
Żywolewska K. (2015) Ocena okresowa nauczyciela akademickiego [in:] W. Sanetra (red.), Zatrudnienie nauczycieli akademickich, Warszawa.

\section{Court sentences}

The decision of the Supreme Court of the 25 June 2004, V KK 74/04, Legalis.

The judgment of the Supreme Administrative Court of 18 August 2010, I OSK 775/10, LEX 737508.

The judgment of the Supreme Administrative Court of 19 April 2011, I OSK 125/11, CBOSA. The judgment of the Supreme Administrative Court of 30 January 2014, I OSK 1978/13, CBOSA. The judgment of the Supreme Administrative Court of 10 April 2015, I OSK 1108/14, CBOSA. The judgment of the Supreme Administrative Court of 8 July 2015, I OSK 1530/14, CBOSA. The judgment of the Voivodeship Administrative Court in Gliwice of 31 May 2016, IV SAB/ Gl 52/16, Legalis.

\section{Legal acts}

The Constitution of the Republic of Poland of 2 April 1997, Dz.U. 1997, No. 78, item 483 as amended.

The Act of 13 July 1920 on academic institutions, Dz.U. 1920, No. 72, item 494 as amended.

The Ordinance of the President of the Republic of Poland of 24 February 1928 on the service relationship of professors of public academic institutions and auxiliary academic staff of such schools, Dz.U. 1933, No. 76, item 551.

The Act of 15 March 1933 on academic institutions, Dz.U. 1938, No. 1, item 6 consolidated text, as amended.

The Act of 15 December 1951 on higher education and academic staff, Dz.U. 1956, No. 45, item 205 consolidated text, as amended.

The Act of 5 November 1958 on higher education, Dz.U. 1973 nr 32 poz. 191 consolidated text. The Act of 27 April 1972—Charter of teacher's rights and obligations, Dz.U. 1972, No. 16, item 114 as amended.

The Labour Code Act of 26 June 1974, Dz.U. 2019, item 1040 consolidated text, as amended. The Act of 5 May 1982 on higher education, Dz.U. 1985, No. 42, item 201 consolidated text, as amended.

The Act of 6 April 1990 on the Police, Dz.U. 2020, item 360 consolidated text, as amended.

The Act of 12 September 1990 on higher education, Dz.U. 1990, No. 65, item 385 as amended. The Act of 6 June 1997-Penal Code, Dz.U. 2019, item 1950 consolidated text, as amended.

The Act of 27 July 2005-Higher education law, Dz.U. 2017, item 2183 consolidated text, as amended.

The Act of 21 July 2007-Law of the common courts system, Dz.U. 2020, item 365 consolidated text, as amended.

The Act of 21 November 2008 on self-government employees, Dz.U. 2019, item 1282 consolidated text. 
The Act of 21 November 2008 on civil service, Dz.U. 2020, item 265 consolidated text.

The Act of 18 March 2011 amending the acts-Higher education law, the Act on academic degrees and title and arts degrees and title and amending certain other acts, Dz.U. 2011, No. 84, item 455.

The Act of 3 July 2018 implementing the Act on higher education and science, Dz.U. 2018, item 1669.

The Act of 20 July 2018-Law on higher education and science, Dz.U. 2020, item 85 consolidated text, as amended.

The Ordinance of the Ministry of Higher Education and Science of 25 September 2018 on the specific mode of mediation, clarification and disciplinary proceedings in cases of disciplinary liability of university teachers, as well as the manner of enforcement and expungement of disciplinary penalties, Dz.U. 2018, item 1843. 